\title{
Basicity Optimization of KF/Ca-MgO Catalyst using Impregnation Method
}

\author{
Didi Dwi Anggoro*, Luqman Buchori, Setia Budi Sasongko, Herawati Oktavianty
}

Department of Chemical Engineering, Diponegoro University, Jl. Prof. Soedharto, Kampus Undip Tembalang, Semarang 50239, Indonesia

Received: $25^{\text {th }}$ January 2019; Revised: $11^{\text {th }}$ May 2019; Accepted: $20^{\text {th }}$ May 2019; Available online: 30 ${ }^{\text {th }}$ September 2019; Published regularly: December 2019

\section{Abstract}

This research aimed at determining the optimum value between calcination temperature $\left(X_{1}\right)$, calcination time $\left(X_{2}\right)$ and \%wt $\mathrm{KF}\left(X_{3}\right)$ toward optimum basicity of $\mathrm{KF} / \mathrm{Ca}-\mathrm{MgO}$ catalyst. Approximately $2-4 \%$ wt $\mathrm{KF}$ was added to the $\mathrm{KF} / \mathrm{Ca}-\mathrm{MgO}$ catalyst using the impregnation method to assist the Ca$\mathrm{MgO}$, at $450-550{ }^{\circ} \mathrm{C}$ and a calcination time of $2-4$ hours. Furthermore, its basicity was analyzed using Tanabe's titration method. The use of Variance Analysis (ANOVA), indicated that calcination temperature $\left(X_{1}\right)$ factor achieved the highest basicity of $\mathrm{KF} / \mathrm{Ca}-\mathrm{MgO}$ catalyst, as indicated by its high $F$-value (16.46262) and low $p$-value (0.0067). The correlation between each operating variables and the responses were shown in a mathematical equation. The optimization value is estimated by limiting the calcination temperature from 415.9 to $584.1{ }^{\circ} \mathrm{C}$, with a calcination time ranging from 1.32 to 4.68 hours, and \%wt KF of 1.3182 to $4.6818 \%$ that obtained $1.18 \mathrm{mmol} / \mathrm{g}$ for the optimal catalyst basicity. Copyright $\odot 2019$ BCREC Group. All rights reserved

Keywords: KF/Ca-MgO catalyst; Basicity; Optimization; Response Surface Methodology

How to Cite: Anggoro, D.D., Buchori, L., Sasongko, S.B., Oktavianty, H. (2019). Basicity Optimization of $\mathrm{KF} / \mathrm{Ca}-\mathrm{MgO}$ Catalyst using Impregnation Method. Bulletin of Chemical Reaction Engineering \& Catalysis, 14(3): 678-682 (doi:10.9767/bcrec.14.3.4248.678-682)

Permalink/DOI: https://doi.org/10.9767/bcrec.14.3.4248.678-682

\section{Introduction}

Potassium Fluoride (KF) is an alkaline halide molecule with an active and reactive $\mathrm{F}$ (fluorine) element, making it easier to rebound with metals. An increase in its effects leads to a higher catalyst activity [1-5]. However, when it is added in surplus, it decreases the catalyst activity. This has been proven by Wen et al. [6] during research by adding $\mathrm{KF}$ in $\mathrm{CaO}$, where its addition above $25 \%$, decreased the catalyst ac-

* Corresponding Author.

E-mail: anggorophd@gmail.com (D.D. Anggoro);

Telp. : +62-24-7460058, Fax: +62-24-76480675 tivity. When the amount is large, it covers the surface of the catalyst, thereby reducing its activity. Hu et al. [7] also conducted a study of the addition of $\mathrm{KF}$ in several catalysts, such as $\mathrm{CaO}-\mathrm{Fe}_{3} \mathrm{O}_{4}, \quad \mathrm{SrO}-\mathrm{Fe}_{3} \mathrm{O}_{4}$, and $\mathrm{MgO}-\mathrm{Fe}_{3} \mathrm{O}_{4}$ in which each had the optimum condition with the addition of KF. This was shown from the acquisition of biodiesel. According to $\mathrm{Hu}$ et al. [7], the obtained biodiesel was high assuming the addition of $\mathrm{KF}$ reaches $25 \%$ for $\mathrm{CaO}, 35 \%$ for $\mathrm{MgO}$, and $10 \%$ for $\mathrm{SrO}$.

The dispersion of active metals to the surface of the solid material is capable of expanding the catalyst surface and increasing the number of 
active sites. Furthermore, when the contact between the reactants and the catalyst increases, the reaction would be more comfortable and faster [8-13]. Another aim of using the carrier is to regulate the amount of metal required as well as to increase the catalyst activity and workability [14-15].

The classical method of optimization involves varying one parameter at a specific time while keeping the other constant. However, this method is inefficient as it fails to understand the relationships between variables (reaction time, temperature, molar ratio) and percentage yield [16-17]. Response Surface Methodology (RSM) is a valid statistical technique used to estimate complex processes. Its main advantage is in the reduction of experimental runs number required to provide adequate acceptable information statistically. It is an easy and cheap technique used to gather research results than the classical method [18]. RSM technique has been successfully applied in the field of quality experimental work [1922].

The treatment processes/sol-gel used in this research is in three stages, namely impregnation, drying, and calcination. Furthermore, the study aims to analyze the optimum basicity of

Table 2. Basicity value of catalyst at various $\% \mathrm{wt} \mathrm{KF}$, calcination temperature, and calcination time

\begin{tabular}{ccccc}
\hline Run & $\begin{array}{c}\text { Calcination } \\
\text { Temperature } \\
\left(\mathrm{X}_{1},{ }^{\circ} \mathrm{C}\right)\end{array}$ & $\begin{array}{c}\text { Calcination } \\
\text { Time }\left(\mathrm{X}_{2},\right. \\
\text { minutes })\end{array}$ & $\begin{array}{c}\text { \%wt } \\
\mathrm{KF} \\
\left(\mathrm{X}_{3}, \%\right)\end{array}$ & $\begin{array}{c}\text { Basicity } \\
(\mathrm{mmol} / \mathrm{g})\end{array}$ \\
\hline 1 & 450 & 120 & 2 & 0.30 \\
2 & 450 & 120 & 4 & 0.64 \\
3 & 450 & 240 & 2 & 0.54 \\
4 & 450 & 240 & 4 & 1.04 \\
5 & 550 & 120 & 2 & 0.84 \\
6 & 550 & 120 & 4 & 0.98 \\
7 & 550 & 240 & 2 & 0.66 \\
8 & 550 & 240 & 4 & 1.18 \\
9 & 416 & 180 & 3 & 0.28 \\
10 & 584 & 180 & 3 & 0.72 \\
11 & 500 & 79 & 3 & 0.92 \\
12 & 500 & 280 & 3 & 1.16 \\
13 & 500 & 180 & 1.32 & 0.96 \\
14 & 500 & 180 & 4.68 & 1.10 \\
$15(\mathrm{C})$ & 500 & 180 & 3 & 1.06 \\
$16(\mathrm{C})$ & 500 & 180 & 3 & 1.04 \\
\hline
\end{tabular}

$\mathrm{KF} / \mathrm{Ca}-\mathrm{MgO}$ catalyst $(Y)$ concerning calcination temperature $\left(X_{1}\right)$, calcination time $\left(X_{2}\right)$, and \%wt $\operatorname{KF}\left(X_{3}\right)$.

\section{Materials and Methods}

Magnesium acetate, calcium nitrate, and citric acid compounds were weighed according to the predetermined calculations and dissolved in $95 \%$ ethanol. All three solutions are stirred at $350 \mathrm{rpm}$ with the temperature of sol at $80{ }^{\circ} \mathrm{C}$ until the color became clear. The formed gel was then dried at $110^{\circ} \mathrm{C}$ for 6 hours by using an oven. The catalyst obtained was mashed using a mortar and calcined for 3 hours at $550{ }^{\circ} \mathrm{C}$ using a furnace. Impregnation of $\mathrm{Ca}-\mathrm{MgO}$ will be achieved by dissolving $\mathrm{KF}$ with \%wt between the ranges of 2-4\% in deionized water, after which it was stirred for 1 hour. Furthermore, the absorbed water was extracted from the catalysts surface by exposing it to $140{ }^{\circ} \mathrm{C}$ for 6 hours and calcined at $450-550$ ${ }^{\circ} \mathrm{C}$ with a time range of $2-4$ hours. The basicity of $\mathrm{KF} / \mathrm{Ca}-\mathrm{MgO}$ catalyst was further analyzed using the Tanabe's titration method.

\section{Results and Discussion}

The experimental design matrix designed using the central composite design method and results of the basicity of $\mathrm{KF} / \mathrm{Ca}-\mathrm{MgO}$ catalyst values are shown in Table 1 . The result consists of 16 sets of coded condition expressed in natural values. The design consists of eight factorial, six axial, and three central points. The sequence of the experiment was randomized to minimize the effects of uncontrolled factors.

The Analysis of Variance (ANOVA), used to analyze the basicity of $\mathrm{KF} / \mathrm{Ca}-\mathrm{MgO}$ catalyst was shown in Table 2. The significance between each factor stated in Table 2 was tested

Table 1. ANOVA results (df: degree of freedom)

\begin{tabular}{lcccc}
\hline \multicolumn{1}{c}{ Variant } & Coefficient & F-value & $\mathrm{df}$ & p-value \\
\hline $\mathrm{X}_{0}$ (const.) & 1.056990 & & & \\
$\mathrm{X}_{1}$ & 0.137659 & 16.46213 & 1 & 0.006670 \\
$\mathrm{X}_{1}{ }^{2}$ & -0.211329 & 26.31767 & 1 & 0.002157 \\
$\mathrm{X}_{2}$ & 0.077883 & 5.26935 & 1 & 0.061478 \\
$\mathrm{X}_{2}{ }^{2}$ & -0.020410 & 0.24547 & 1 & 0.637901 \\
$\mathrm{X}_{3}$ & 0.127075 & 14.02814 & 1 & 0.009561 \\
$\mathrm{X}_{3}{ }^{2}$ & -0.023945 & 0.33789 & 1 & 0.582214 \\
$\mathrm{X}_{1} \mathrm{X}_{2}$ & -0.077500 & 3.05647 & 1 & 0.131003 \\
$\mathrm{X}_{1} \mathrm{X}_{3}$ & -0.022500 & 0.24762 & 1 & 0.629872 \\
$\mathrm{X}_{2} \mathrm{X}_{3}$ & 0.067500 & 2.31859 & 1 & 0.178664 \\
\hline
\end{tabular}


using the $F$ - and $p$-values. High $F$ and $p$ values lower than 0.05 indicates that the variables significantly influenced the response studied. The $F$-value illustrates the ratio between Mean Square of Factor (MSF) and Mean Square of Error (MSE). The effect of operating these variables is shown in Table 2.

The higher basicity of high $F$-value (16.462) and low $p$-value (0.0067) was illustrated in ANOVA Table 2. The objective function of this test is used to determine the optimum basicity value between calcination temperature, time, and \%wt KF. The relation between each operating variables and the responses is shown in Equation (1).

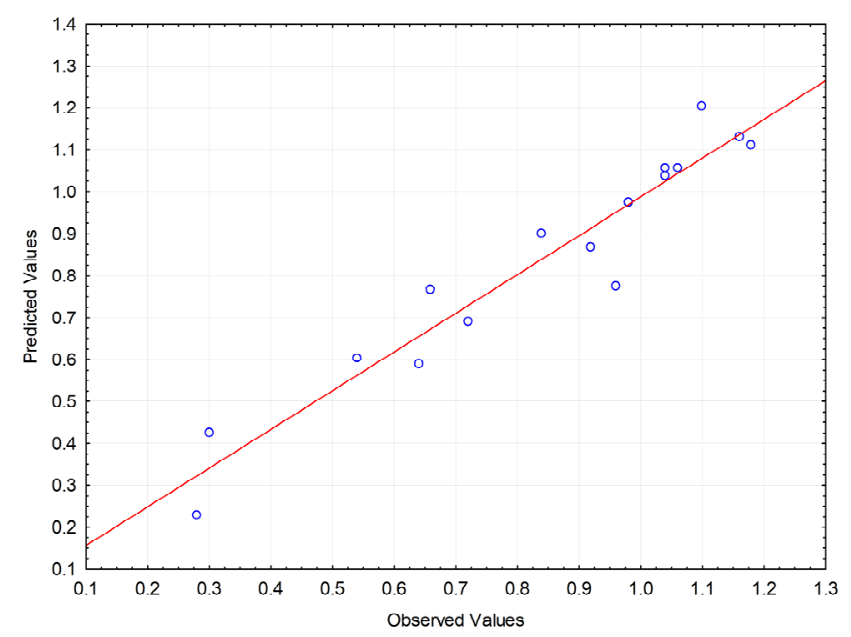

Figure 1. Correlation of predicted and observed value of $\mathrm{KF} / \mathrm{Ca}-\mathrm{MgO}$ catalyst basicity

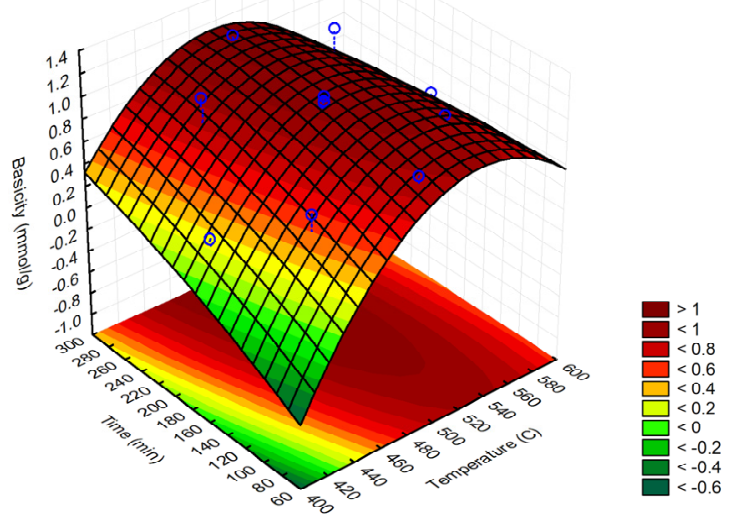

Figure 2. Surface plot of correlation between calcination time and calcination temperature on the basicity of catalysts generated at center point.

$$
\begin{aligned}
Y= & 1.05699+0.13766 X_{1}-0.21133 X_{12}+ \\
& 0.07788 X_{2}-0.02041 X_{22}+0.12708 X_{2}- \\
& 0.02395 X_{32}-0.0775 X_{1} X_{2}-0.0225 X_{1} X_{3} \\
& +0.0675 X_{2} X_{3}+0.0675 X_{2} X_{3}
\end{aligned}
$$

The order of this equation is selected by correlating the coefficient of determination $\left(\mathrm{R}^{2}\right)$ for the mathematical equation is $92.37 \%$.This value indicates a match between the predicted value and experimental data shown in Figure 1. The linear line shown in Figure 1 is called a regression line, which indicated the best prediction between independent variables $(X)$ against dependent variables $(Y)$. However, it is not perfectly predictable, with a substantial reoccurring variation of the observed points around the fitted regression line (Figure 1). Residual value is defined as the deviation of a specific point from the regression line (the predicted value).

In Figure 2, the 3D surface graph shows the correlation between temperature and time of calcination, with a temperature range of 450 to $550{ }^{\circ} \mathrm{C}$. Furthermore, it reaches the optimum basicity level, due to the temperature range of 450 to $550{ }^{\circ} \mathrm{C}$ with a change in the catalyst composition, which affects its basicity. This is by the research conducted by Xie and Huang [23] where the basicity value of the catalyst with the addition of $\mathrm{KF}$ on the $\mathrm{KF} / \mathrm{ZnO}$ decreased after when the temperature exceeds $550{ }^{\circ} \mathrm{C}$. The $3 \mathrm{D}$ surface graph in Figure 3 shows that an increase in \%wt KF leads to an increase in its basicity. Therefore, its addition affects its level [24]. Figure 4 shows the correlation between the calcination time and \%wt $\mathrm{KF}$, which failed to contribute to the increase

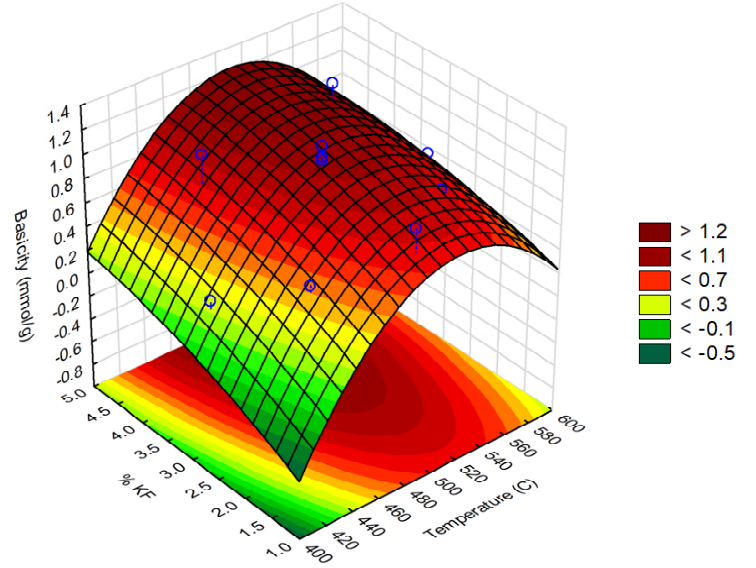

Figure 3. Surface plot of correlation between calcination temperature and \% $\mathrm{KF}$ on the basicity of catalysts generated at center point 
of catalyst basicity. The longer the calcination time, the higher the catalyst basicity value, however, it does not give a significant improvement. This shows that the addition of KF support to the $\mathrm{CaO}-\mathrm{MgO}$ is the dominant factor which helps increase catalyst activity leading to higher basicity [6].

\section{Conclusions}

The optimized operating condition of the catalyst production is easily estimated by limiting the calcination temperature in ranges of 415.9 to $584.1^{\circ} \mathrm{C}$, the time between 1.32 to 4.68 hours, and the \%wt KF content ranging from 1.3182 to $4.6818 \%$. This obtained an optimal catalyst basicity value of $1.18 \mathrm{mmol} / \mathrm{g}$. The correlation between calcination temperature $\left(X_{1}\right)$, calcination time $\left(X_{2}\right)$, \%wt $\mathrm{KF}\left(X_{3}\right)$ and the catalyst basicity $(Y)$ is shown in Equation (1).

\section{Acknowledgements}

The authors are grateful to financial support from Indonesian Ministry of Research, Technology and Higher Education (Kemenristekdikti) under 2018 budget year.

\section{References}

[1] Guzmán-Vargasa, A., Santos-Gutiérreza, T., Limab, E., Flores-Morenoc, J.L., OliverTolentinoa, M.A., de J. Martínez-Ortiza, M. (2015). Efficient KF loaded on MgCaAl hydrotalcite-like compounds in the transesterification of Jatropha curcas oil. Journal of Alloys and Compounds, 643: S159-S164.

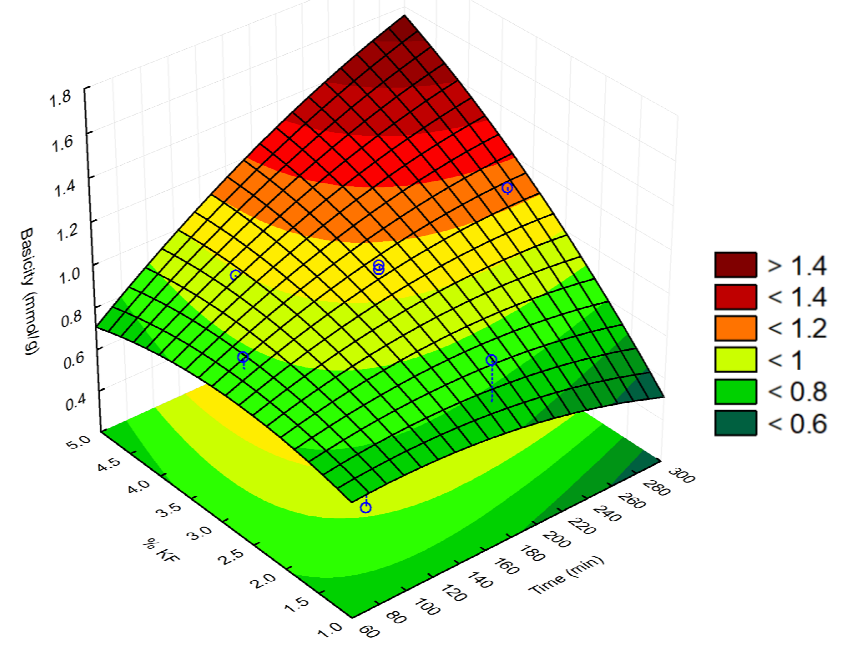

Figure 4. 3D surface of the correlation between calcination time and \% $\mathrm{KF}$ on the performance of catalysts generated at center point
[2] Liu, H., Su, L., Shao, Y., Zou, L., (2012). Biodiesel production catalyzed by cinder supported $\mathrm{CaO} / \mathrm{KF}$ particle catalyst. Fuel, 97: 651657.

[3] Xuan, J., Zheng, X., Hu, H., (2012). Active sites of supported KF catalysts for transesterification. Catalysis Communications, 28: 124 -127 .

[4] Bai, R., Wang, S., Mei, F., Li, T., Li, G., (2011). Synthesis of glycerol carbonate from glycerol and dimethyl carbonate catalyzed by KF modified hydroxyapatite. Journal of Industrial and Engineering Chemistry, 17: 777781.

[5] Kabashima, H., Tsuji, H., Nakatab, S., Tanaka, Y., Hattori, H., (2000). Activity for base-catalyzed reactions and characterization of alumina-supported KF catalysts. Applied Catalysis A: General, 194-195: 227-240.

[6] Wen, L., Wang, Y., Lu, D., Hu, S., Han, H. (2010). Preparation of $\mathrm{KF} / \mathrm{CaO}$ Nanocatalyst and its Application in Biodiesel Production from Chinese Tallow Seed Oil. Fuel, 89: 22672271.

[7] Hu, S., Wang, Y., Han, H. (2011). Utilization of Waste Freshwater Mussel Shell as an Economic Catalyst for Biodiesel Production. Biomass Bioenergy, 35: 3627-3635.

[8] Satterfield, C.N. (1991). Heterogeneous Catalysis in Industrial Practice. New York: Mc. Graw Hill Book, Co.

[9] Anderson, J.T., and Boudart, M. (1989). Catalysis, Science and Technology. New York: Springer-Verlag.

[10] da Costa Evangelista, J.P., Gondim, A.D., di Souza, L., Araujo, A.S., (2016). Aluminasupported potassium compounds as heterogeneous catalysts for biodiesel production: A review. Renewable and Sustainable Energy Reviews, 59: 887-894.

[11] Nakamura, R., Komura, K., Sugi, Y., (2008). The esterification of glyceride with lauric acid catalyzed by multi-valent metal salts. Selective formation of mono-dilaurins. Catalysis Communications, 9: 511-515.

[12] Barrault, J., Bancquart, S., Pouilloux, Y., (2004). Preliminary communication / Communication Selective glycerol transesterification over mesoporous basic catalysts. $C . R$. Chimie, 7: 593-599.

[13] Anggoro, D.D., Putra, R.R., Oktavianty, H., Kamilah, L.A., Chamdani, F.T., (2018). Dealumination and Characterization of ZSM5 as Catalyst for Glycerol Conversion to Glycerol Monolaurate. Reaktor, 18 (2): 110-116. 
[14] Anggoro, D.D., Hidayati, N., Buchori, L., Mundriyastutik, Y., (2016). Effect of Co and Mo Loading by Impregnation and Ion Exchange Methods on Morphological Properties of Zeolite Y Catalyst. Bulletin of Chemical Reaction Engineering \& Catalysis, 11 (1): 75-83.

[15] Anggoro, D.D., Buchori, L., Silaen, G.C., Utami, R.N., (2017). Preparation, Characterization, and Activation of $\mathrm{Co}-\mathrm{Mo} / \mathrm{Y}$ Zeolite Catalyst for Coal Tar Conversion to Liquid Fuel. Bulletin of Chemical Reaction Engineering \& Catalysis, 12 (2): 219-226.

[16] Hamsaveni, D.R., Prapulla, S.G., Divakar, S. (2001). Response surface methodological approach for the synthesis of isobutyl isobutyrate. Process Biochem., 36: 1103-1109.

[17] Soo, E.L., Salleh, A.B., Basri, M., Rahman, R.N.Z.A., Kamaruddin, K. (2004). Response surface methodological study on lipasecatalyzed synthesis of amino acid surfactants. Process Biochem., 39: 1511-1518.

[18] Shieh, C.J., Akoh, C.C., Koehler, P.E. (1995). Four-factor response surface optimization of the enzymatic modification of triolein to structured lipids. J. Am. Oil Chem. Soc. 72: 6

[19] Anggoro, D.D., Buchori, L., Istadi, I., Fadhil, R.P., Antonio, G. (2018). Optimization of Preparation of Zeolite Y Dealuminate Catalysts for Glycerol Conversion to Glycerol Mono Laurate. MATEC Web of Conferences (RSCE 2017). 156:06006.
[20] Anggoro, D.D., Istadi, I. (2008). Optimization of methane conversion to liquid fuels over WCu/ZSM-5 catalysts by response surface methodology. J. of Nat. Gas Chem. 17: 39-44.

[21] Amin, N.S.A., Anggoro, D.D. (2004). Optimization of direct conversion of methane to liquid fuels over Cu loaded. Fuel. 83:487-494.

[22] Chakraborty, R., Mandal, E. (2015). Fast and energy efficient glycerol esterification with lauric acid by near and far-infrared irradiation: Taguchi optimization and kinetics evaluation. Journal of the Taiwan Institute of Chemical Engineers, 50: 93-99.

[23] Xie, W., Huang, X. (2006). Synthesis of Biodiesel from Soybean Oil using Heterogeneous $\mathrm{KF} / \mathrm{ZnO}$ Catalyst. Catalysis Letters, 107: 5359.

[24] Wang, Y., Hu, S., Guan, Y., Wen, L., Han, H. (2009). Preparation of Mesoporous Nanosized $\mathrm{KF} / \mathrm{CaO}-\mathrm{MgO}$ Catalyst and its Application for Biodiesel Production by Transesterification. Catal. Lett., 131:574-578.

Selected and Revised Papers from The $3^{\text {rd }}$ International Conference on Chemical and Material Engineering (ICCME) 2018 (http://iccme2018.undip.ac.id) (Diponegoro University, by $19^{\text {th }}$-20 ${ }^{\text {th }}$ September 2018) after Peer-reviewed by Scientific Committee of ICCME 2018 and Peer-Reviewers of Bulletin of Chemical Reaction Engineering \& Catalysis 